\title{
DETERMINANTS OF THE INNOVATIVE AND INVESTMENT DEVELOPMENT OF AGRICULTURE
}

\author{
aNatalia V. Trusova*, boksana V. Hryvkivska, bNataliia M. Kotvytska, aSvitlana A. Nesterenko, \\ aTetiana I. Yavorska, colha V. Kotyk \\ a Dmytro Motornyi Tavria State Agrotechnological University, Melitopol, Ukraine. \\ ${ }^{b}$ European University, Kyiv, Ukraine. \\ cNational University of Water and Environmental Engineering, Rivne, Ukraine.
}

\section{ART ICLE INFO}

\section{Article History}

Received: April 21, 2021

Revised: July 1, 2021

Accepted: July 30, 2021

\section{Keywords}

Intersectoral cooperation

Economic entities

estimation

Investors

Technological cycle
A B S T R A C T

The article considers the conditions for the formation of determinants of innovativeinvestment development of agriculture. A systematic approach to the development of agriculture in a single integration space of intersectoral cooperation and state support through the introduction of effective innovative and investment determinants, which form the criteria of investment attractiveness of economic entities and provide conditions for innovation in production and technological process, is implemented. The levels of innovative and investment development of agriculture are structured. Determinants of innovative and investment development of agriculture and indicators of its estimation are offered. A comprehensive methodological approach to financing innovative and investment projects with state guarantees to potential investors to obtain additional value from the introduction of scientific development in the technological cycle of agricultural production, taking into account economic, social, budgetary, environmental, resource, intellectual, scientific and technical components of innovative and investment processes proposed. It is recommended to evaluate the effectiveness of the introduction of innovations in agriculture by an integrated indicator with the ratio of effects (results) and costs by certain components. Scientific organizations by sectors of activity, which include development in innovative and investment development of agriculture of Ukraine, are analysed. An assessment of innovative and investment activity of Ukrainian producers with the distribution of the average number of employees in agriculture is carried out. The share of expenditures on research and development on agricultural development in the gross domestic product (GDP) of EU-28 countries and Ukraine is determined. The calculation of priority factors of external and internal environment of influence on the efficiency of innovative and investment development of the animal husbandry industry is carried out. The forecast values of functional risks and the level of efficiency of innovative and investment development of the animal husbandry industry of Ukraine are determined.

Corresponding Author: Natalia V. Trusova

Email: nvtrusova7305-1@ubogazici.in

(C) The Author(s) 2021.

\section{INTRODUCTION}

Sustainable economic growth of agriculture requires a high level of scientific support of production (science, technology, and production experience, scientific and technical personnel) and intellectualization of production processes. That is, the perception and 
implementation of new radical and modified ideas should be a prerequisite for their implementation in the economic activities of agricultural entities in a competitive market environment. However, the aggravation of a number of existing systemic problems in agriculture due to the deterioration of material and technical base, unequal exchange of agricultural products for industrial resources, narrows the investment and financial component of economic entities and weakens their innovation activity.

The necessary search for new determinants of innovative and investment development of agriculture, focused on increasing agricultural production, increasing GDP, allows a significant intensification of the use of investment, innovation, information and other resources. Accordingly, the implementation of innovative processes in agriculture should increase the country's food security, providing the population with food in the required quantity and quality, and industry with raw materials.

According to world experience, direct active and indirect passive indicative intervention of determinants of agricultural development in the field of crop and animal husbandry, allows intensifying and significantly increasing investment in innovation activities of economic entities. This creates incentives and conditions for the development of innovations, contributes to the effective formation of their costs, and realizes the necessary elasticity of investment resources in accordance with the intermediate stages of the innovation process.

Various aspects of evaluating the effectiveness of innovation processes in the economy have been studied by: Castellacci and Natera (2013); Freeman (1987); Hekkert et al. (2007),Mensh (1975),Patel and Pavitt. (1994), Nelson et al. (2006), Perroux (1950), Prokopenko et al. (2014) and Prokopenko et al. (2019a). A significant number of scientists studied the theoretical, methodological and practical principles of innovative and investment development of agriculture: Cherep and Chernikova (2019), Humenyuk et al. (2020), Khalatur et al. (2020), Khalatur (2017), Kleinknecht (1987),
Lundvall (2007), Pavlova et al. (2019), Prokopenko et al. (2019a), Purvis and Downey. (2012) and Winter (1984). Simultaneously with the coverage of theoretical and practical problems of individual components of innovative and investment development, some issues need detailed elaboration, especially in connection with the expansion and diversification of innovation infrastructure to implement various options to stimulate agricultural development based on economic mechanism and marketing methods, which support this process.

The priority of this study is to develop a systematic approach to agricultural development in a single integration space of intersectoral cooperation and state support through the introduction of effective innovative and investment determinants that form criteria for investment attractiveness of economic entities and provide conditions for innovation in production and technological process.

\section{MATERIALS AND METHODS}

Activation of innovative and investment development of agriculture is considered from the standpoint of longwave fluctuations in the agricultural sector of the economy and is associated with technological transformations, enhanced capabilities of organizational, production, management cycles that provide the basic structure of innovation.

In this case, the innovative environment of agriculture and a set of exogenous and endogenous conditions allows to obtain economic benefits from the commercialization of production and technological process, which is associated with measuring the effectiveness of innovation in the economic system of agricultural producers, on the one hand, and the susceptibility of this system to innovation - on the other hand.

The institutionalization of agricultural innovation is manifested in the ability of the economic system of the macro, meso or micro level to promote the production, implementation and development of innovations (Figure 1). 


Criteriaandproperties
he ability of agriculture to produce products and provide innovative services that
markets

Figure 1. Structuring the levels of innovation and investment development of agriculture.

The study of the ontological preconditions of innovative and investment development of agriculture requires not only the definition of basic criteria, but also the selection of a number of determinants, in particular: intellectual capital; use of new knowledge and technologies; innovation infrastructure; research and development; investments; technological exchange; social and environmental component of innovation. Thus, intellectual capital is the main determinant of innovative and investment development of agriculture, which on the set of knowledge, skills, abilities of individuals, forms basic research aimed at meeting the needs of agricultural producers in order to use the latest innovative technologies in economic activities to address specific economic issues modernization of the production process and its commercialization in the extensive intersectoral network of the economic system. Innovation infrastructure strengthens the sectoral structure of agriculture, creating jobs, developing production technologies, ensuring the implementation of innovative and investment activities of agricultural producers. At the same time, the implementation of innovative and investment activities of economic entities in the intersectoral space of agriculture on a set of indicators reflects the effectiveness of the action to implement a new or improve the existing production and technological process. They should include:

1 ) indicators of the share of innovative products in its total volume (the share of created and advanced production technologies in the total number of used advanced production technologies, the share of innovative products in the total volume of agricultural products shipped; weight of innovative products in the total volume of sold products of economic entities that have carried out technological innovations);

2 ) indicators that characterize the impact of innovation on the results of economic activity (gross national or regional product per capita).

Table 1. Determinants of innovative and investment development of agriculture and indicators of its evaluation.

\begin{tabular}{|c|c|}
\hline Factors & Criteria and indicators \\
\hline Intellectual capital & $\begin{array}{l}\text { the number of personnel engaged in research and development, per } 10 \text { thousand } \\
\text { persons employed in agriculture, persons; the ratio of students admitted to higher } \\
\text { education institutions and graduates; the share of employees of institutions that have } \\
\text { a scientific degree in the total number of employees of organizations engaged in } \\
\text { research and development, \%; costs of organizations for education and training } \\
\text { related to innovation, million EUR. }\end{array}$ \\
\hline $\begin{array}{l}\text { Basic research and } \\
\text { development }\end{array}$ & $\begin{array}{l}\text { number of created advanced technologies, units; coefficient of inventive activity } \\
\text { (number of patent applications per } 10 \text { thousand people); total research and }\end{array}$ \\
\hline
\end{tabular}




\begin{tabular}{|c|c|}
\hline & $\begin{array}{l}\text { development, million EUR; costs of institutions for research and development of new } \\
\text { agricultural products, services and methods of their production (transfer), new } \\
\text { production processes, million EUR; research and development costs for gross regional } \\
\text { product, \% }\end{array}$ \\
\hline Using new technologies & $\begin{array}{l}\text { the number of used advanced production technologies, units; costs of institutions for } \\
\text { technological innovations, million EUR; costs of agricultural producers for the } \\
\text { acquisition of rights to patents, licenses, use of inventions, utility models, million EUR; } \\
\text { the share of granted patents for inventions and utility models in the total amount of } \\
\text { filed applications for inventions and utility models, \%; innovative activity of business } \\
\text { entities, \%. }\end{array}$ \\
\hline $\begin{array}{l}\text { The use of innovations } \\
\text { and the effectiveness of } \\
\text { innovative and } \\
\text { investment activities }\end{array}$ & $\begin{array}{l}\text { the share of advanced production technologies used in the total number of created } \\
\text { ones, \%; the share of innovative products in the total volume of agricultural products } \\
\text { of economic entities shipped, \%; the share of innovative products in the total volume } \\
\text { of sold products of economic entities engaged in technological innovations, \%; gross } \\
\text { regional product per capita, EUR. }\end{array}$ \\
\hline Innove & $\begin{array}{l}\text { the share of agricultural producers who carry out technological innovations in the } \\
\text { total number of surveyed enterprises, \%; the number of agricultural producers who } \\
\text { participated in the development of joint projects for research and development; the } \\
\text { number of organizations that provide training and education of personnel related to } \\
\text { innovation, units. }\end{array}$ \\
\hline Investments & $\begin{array}{l}\text { share of foreign investments in total expenditures on technological innovations, \%; the } \\
\text { share of own funds of agricultural producers in financing the total cost of technological } \\
\text { innovations, \%; share of other funds in financing technological innovations, \%; the } \\
\text { share of the state budget in financing the costs of technological innovations, \%; the } \\
\text { share of local budgets in financing the costs of technological innovations, \%; the share } \\
\text { of extra-budgetary funds in financing the costs of technological innovations, \%; fixed } \\
\text { capital investment per capita, thousand EUR. }\end{array}$ \\
\hline Technology exchange & $\begin{array}{l}\text { the share of innovative agricultural products in total exports, \%; the number of joint } \\
\text { innovation and investment projects of agricultural producers with the institutions of } \\
\text { public-private partnership for research and development, units; costs of new } \\
\text { technologies, million EUR; the number of acquired new technologies (technical } \\
\text { achievements), software, units; the number of transferred new technologies (technical } \\
\text { achievements), software, units. }\end{array}$ \\
\hline $\begin{array}{l}\text { The social component of } \\
\text { innovation }\end{array}$ & $\begin{array}{l}\text { projected life expectancy at birth, years; the ratio of monetary income of the } \\
\text { population with the subsistence level, \%; average per capita income (per month), } \\
\text { thousand EUR; unemployment rate, \%; level of economically active population, } \%\end{array}$ \\
\hline $\begin{array}{l}\text { Ecological component of } \\
\text { innovation }\end{array}$ & $\begin{array}{l}\text { specific weight of polluted wastewater in surface water bodies, million cubic meters. } \\
\text { m.; specific weight of neutralization of pollutants in \% of the total amount departing } \\
\text { from stationary sources, \%; share of payments for permissible and excessive } \\
\text { emissions of pollutants, \%; specific weight of pollutant emissions into the air from a } \\
\text { stationary source, \% }\end{array}$ \\
\hline
\end{tabular}

The set of determinants and indicators on the basis of which they are evaluated are presented in Table 1 . We should note that the cyclical pace of agricultural development and the speed of commercialization of innovations in agricultural producers is determined by the duration of diversification of their technological process and the ability of economic entities to adjust the stage of production of new agricultural products, determined by the type of innovative and investment potential of the development of agricultural producers, 
which in essence has a dynamic and cyclical nature, the duration of which is at least a year (Figure 2).

Depending on the strategic programs of agricultural development, the process of long-term (continuous) reproduction of innovative and investment potential for the development of agricultural producers (IIPD) is envisaged. At the same time, the restoration of its stability is associated not only with their quantitative and qualitative properties of the resource component, but also with its level in space and time. Thus, from the standpoint of the past, the sustainability of potential is determined by the set of resources mobilized by agricultural producers and is characterized as achieved (IIPD). Depending on the areas of potential use, namely: simple or extended reproduction of its resource provision, it is possible to allocate exchange and use resources; the resources used in the past activate the reserves to determine the current level of sustainable innovative and investment potential of the development (IIPD2). In terms of type characteristics, it is the available (actual) sustainable innovative and investment potential for the development of agricultural producers. The existing (actual) level of sustainable potential can be reproduced both at the level already reached or below it (IIPD2 $\leq$ IIPD1) and at a higher level (IIPD2 > IIPD1).

Thus, it can be argued that the restoration of quantitative and qualitative system-resource component of innovative and investment potential of agricultural producers on the basis of realization of the amplitude of resource provision opportunities to activate existing reserves by choosing strategic directions of agricultural development in general in a competitive environment will have a stimulating effect on the growth of capital investment, the accumulation of fixed capital in the objects of innovative-investment reproduction in order to make a profit and (or) achieve a positive effect.

State regulation of investment support for innovative development of agricultural producers will allow reproducing the expanded reproduction by providing state guarantors with a limited time to attract budget funding for investment activities of entities to determine their potential state of economic growth, to eliminate shortcomings of the current procedure for selecting alternative innovations for the implementation of which state support is provided within the incentive levers to obtain the expected effect, without losing the interest of economic entities in the reproduction of fixed capital. Therefore, the future state of stability of innovative and investment development potential should be defined as promising (IIPD3 > IIPD2 >IIPD1), i.e. one that is focused on achieving a higher level. However, as already mentioned, depending on the conditions and results of the functioning of agricultural producers in previous periods, their future state may be characterized by a simple reproduction of resource provision (IIPD3 s IIPD1).

Given the new needs of the market, in which consumers are interested not only in price but also in new consumer qualities of products, encourages agricultural development institutions to develop and implement the main directions of state policy in science and technology in the long run. First, it is the creation of mechanisms for state stimulation of scientific and innovative activities and the intensity of development of priority areas of scientific and technical development with the support of the state and its institutions based on the partnership. Moreover, financial and intellectual resources for the implementation of state priorities of innovative and investment development of agriculture should be focused on financing intersectoral cooperation through models of venture investment in science and stimulating high-tech production of agricultural producers (Trusova et al., 2019). This will allow effective interaction in the intersectoral network of innovative-investment development of agriculture and eliminate inequalities in trade with other sectors of the economy. The use of venture capital funds in public-private partnerships and the involvement of scientific organizations in these processes is a guarantee of public authorities to implement large-scale innovative and investment projects at the macro, meso and brand levels to enhance the innovative and investment potential of agricultural producers.

We have proposed a methodological approach to comprehensive financing of innovative and investment projects with giving state guarantees to potential investors to obtain additional value from the introduction of scientific developments in the technological cycle of agricultural production, taking into account economic, social, budgetary, environmental, resource, intellectual and scientific and technical components of the innovative-investment process. The development of this approach will expand the opportunities of agricultural development programs in the region and the state as a whole, meet the needs of potential investors, and increase the efficiency of 
investment resources in the implementation of innovative and investment activities of agricultural producers. The authors propose to evaluate the effectiveness of innovation in agriculture on an integrated basis with the ratio of effects (results) and costs for the above-mentioned components (Table 2). Determining the predicted value of the integrated effect allows taking into account and analyzing the mutual influence of the effects. Thus, the economic effect, which directly provides an increase in the mass of profits, affects through the possibility of higher wages and improved working conditions on the social effect. There is also the opportunity to observe the impact of the latter on productivity growth.

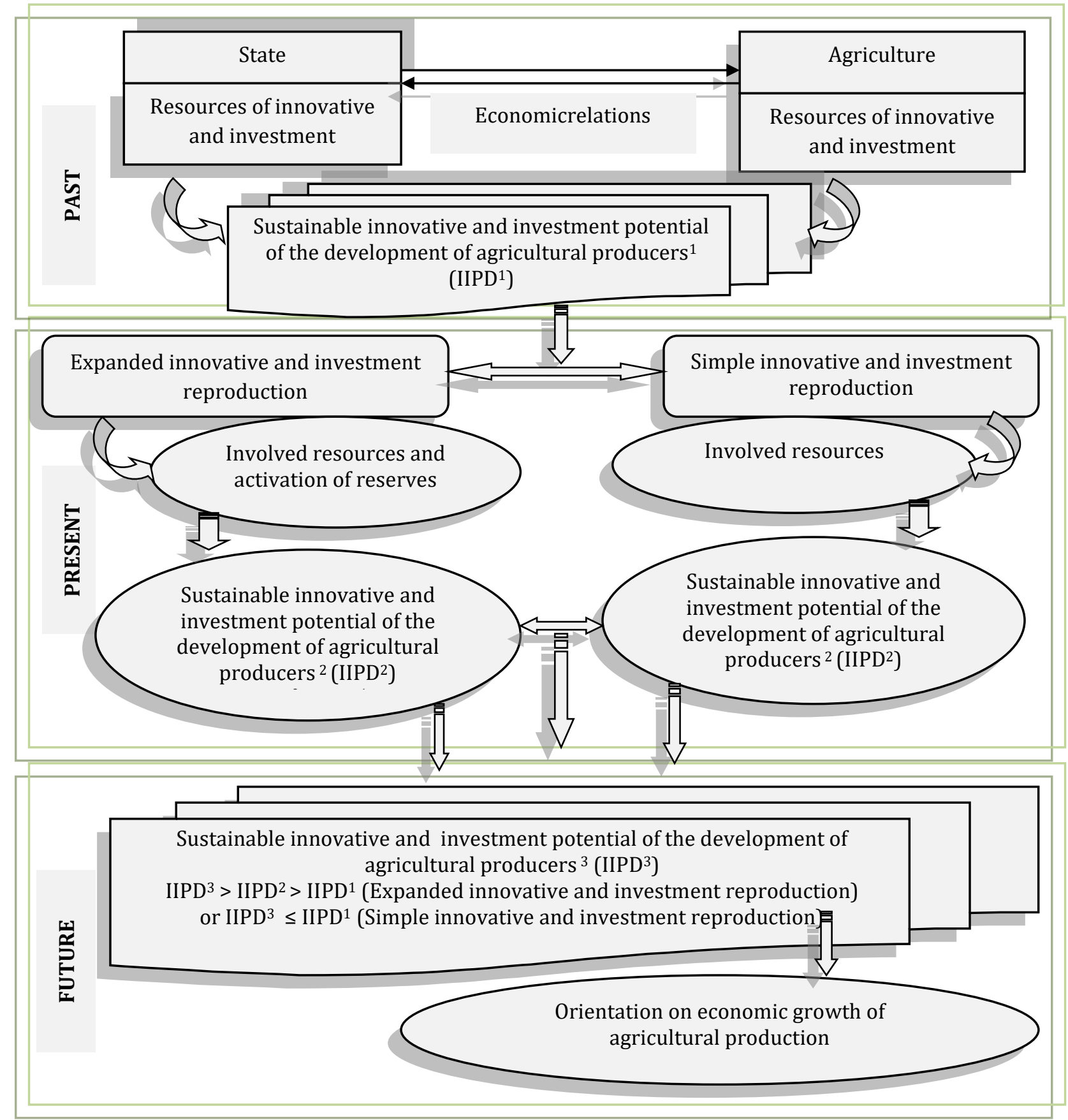

Figure 2. Sustainability of the reproduction process of innovative and investment potential of the development of agricultural producers. 
From the point of view of the budgetary effect, the growth of profitability of agricultural producers in the industry increases taxes and fees, and due to higher wages increases the amount of contributions to social activities, transforming the integral value of the budgetary effect. At the same time, the indicators of the budget effect have a direct impact on the effectiveness of innovative and investment activities of agricultural producers in cooperation with various business structures at the macro, meso and brand levels through revenues and expenditures of the budget. Obtaining a positive value of the budgetary effect provides an opportunity to increase contributions to environmental measures.

Table 2. Components of the integrated effect of the implementation of innovative and investment projects in agriculture.

\begin{tabular}{|c|c|c|}
\hline $\begin{array}{l}\text { Component } \\
s \text { of the } \\
\text { integral } \\
\text { effect (Ei) }\end{array}$ & $\begin{array}{l}\text { Qualitative characteristics of the } \\
\text { components of the effect }\end{array}$ & Calculation algorithm \\
\hline $\begin{array}{l}\text { Economic } \\
\text { effect }\end{array}$ & $\begin{array}{l}\text { Increasing the competitiveness of } \\
\text { agricultural producers, reducing } \\
\text { production costs; increase labor }\end{array}$ & $N P V=\sum_{t=1}^{T} \frac{R_{t}-B_{t}}{(1+r)^{t}}-\sum_{t=1}^{T} \frac{K}{(1+r)^{t}}$ \\
\hline
\end{tabular}
productivity; reduction of material where, NPV - net present value; Rt-gross income at the $\mathrm{t}$ costs; increase in profits of enterprises; th step of project implementation; Bt - gross costs at the tsale of intangible assets th step of project implementation; Kt - investment costs at the $\mathrm{t}$-th step of project implementation; $r$ - discount rate; $\mathrm{T}$ - project implementation period (calculation horizon).

\begin{tabular}{ll}
\hline Resource & Increasing jobs for suppliers of \\
effect & material, technical and innovative \\
& resources in connection with the \\
& attraction of material resources for the \\
& project; reducing the cost, material and \\
& energy consumption of production
\end{tabular}
Scientific New technical and technological, and scientific information; resource-saving technical technologies of agricultural production effect \[ B_{M A T}=B_{P}-B_{D} \]
where, $\triangle$ BMAT - an increase in the cost of raw materials for production; $\mathrm{BP}$ - the amount of raw materials and materials for production after the project; BD - the amount of raw materials and materials for production before the project. $\Delta Z_{n-t}=Z_{P}-Z_{D}$
where, $\Delta \mathrm{Zn-t}$ - increase in the value of scientific and technical knowledge of the enterprise staff; ZP - the amount of knowledge and experience after the project; ZD - the amount of knowledge and experience (level of education, level of qualification, work experience, etc.) before the project.

\begin{tabular}{ll}
\hline Intellectual & Improving the qualification level of \\
effect & performers: employees of agricultural \\
& enterprises and scientific organizations
\end{tabular}
$\Delta V_{I N T}=V_{P}-V_{D}$ where, $\Delta$ VINT - increase in the value of intellectual property; VP - the cost of intellectual property in the enterprise after the project; VD - the cost of intellectual property in the enterprise before the project.

\begin{tabular}{ll}
\hline Ecological & Increase in contributions to \\
effect & environmental and environmental \\
& protection measures; improving the \\
& health of workers and the general \\
& public
\end{tabular}

$$
\begin{aligned}
& \Delta E_{b}=E_{b_{P}}-E_{b_{D}} \\
& \Delta Q_{\text {OTX }}=Q_{P}-Q_{D}
\end{aligned}
$$

where, $\Delta \mathrm{Eb}$ - increase in the amount of fees for air pollution; EbP - the amount of fees for air pollution after the project; EbD- the amount of fees for air pollution before the project; $\triangle \mathrm{QOTX}$ - an increase in the cost of disposal and destruction of industrial waste; QP - the amount of costs for placement and destruction of production waste after the project; QD - the amount of costs for placement and destruction of production waste before the project.

\begin{tabular}{lll}
\hline $\begin{array}{l}\text { Budgetary } \\
\text { effect }\end{array}$ & $\begin{array}{l}\text { Increase in tax revenues and fees by } \\
\text { increasing the profitability of }\end{array}$ where, $\Delta \mathrm{HB}-$ increase in the amount of revenues to the \\
\hline
\end{tabular}


agricultural production

Social Increase in contributions to social

effect activities due to wage growth

budget in the form of taxes; HP - the amount of revenues to the budget in the form of taxes after the project; HD the amount of revenues to the budget in the form of taxes before the project.

$$
\Delta K_{R M}=\left(K_{P}-K_{D}\right) \times Z_{P}
$$

where, $\triangle K R M$ - increase in the number of jobs due to the implementation of an innovative project; KP - the number of jobs after the project; KD - the number of jobs before the project; $\mathrm{ZP}$ - the value of the average wage.

That is, the use of budget investment resources for the introduction of innovations in the environment reflects the level of environmental impact, which is extremely important for regional-sectoral agriculture. Accordingly, the integrated effect for a potential participant of an innovative and investment project according to certain determinants is determined by formula (1) (Purvis and Downey, 2012):

$E_{I i}^{p p}=\sum_{i=1}^{n} E_{i}+\sum_{i \geq j, j=1}^{n} \frac{1}{\frac{a_{i j}}{E_{i}}+\frac{b_{i j}}{E_{j}}}$,

where: $E_{I i}^{p p}$ - the magnitude of the integrated effect of innovation for a potential participant; $E_{i}$ - the magnitude of the i-th, j-th component of the integral effect; $a_{i j}, b_{i j}-$ the value inverse of the share of the contribution of the ith, j-th effects in the synergetic effect, respectively; $n_{-}$ the number of effects from the implementation of an innovative project. Thus, a comprehensive assessment of the integrated effect, taking into account the objective effect of the laws of synergy of innovative and investment projects at the macro, meso and brand levels allows innovative and investment development of agriculture on the basis of state support and guarantees potential investors additional value from intensification of production and technological processes on the platform of intersectoral interaction.

\section{RESULTS AND DISCUSSION}

Modern development of intersectoral cooperation in agriculture is impossible without the introduction and use of innovations and technical and technological solutions, as the level of activation of the latter determines the overall level of competitiveness in both Ukrainian and world markets. The introduction of innovations helps to increase productivity, save various types of resources, reduce costs and reduce the cost of agricultural products, increase volumes and increase production efficiency, which affects investment. World innovation and technological processes of agricultural development are aimed at the dynamism and intensification of intersectoral cooperation using advanced technologies, the safety of some of them has not yet been studied in detail. It should be noted that countries that have achieved high rates of economic growth through the introduction of determinants of innovative and investment development of agriculture (Japan, USA, Germany, France, Great Britain), meet the global requirements of intersectoral innovation. At the same time, their model of economic growth of agriculture is provided by interaction with scientific organizations that form intellectual capital, which is financed from the state budget in the amount ofnot less than $2 \%$ of GDP (in Ukraine this figure is $0.45 \%$ ) (Kasianenko, 2011). Figure 3 presents scientific organizations that conduct research by the sectors of activity on the way to the implementation of projects in innovative and investment development of agriculture in Ukraine, and which ensure the ability of agricultural producers to compete in Ukrainian and world markets.

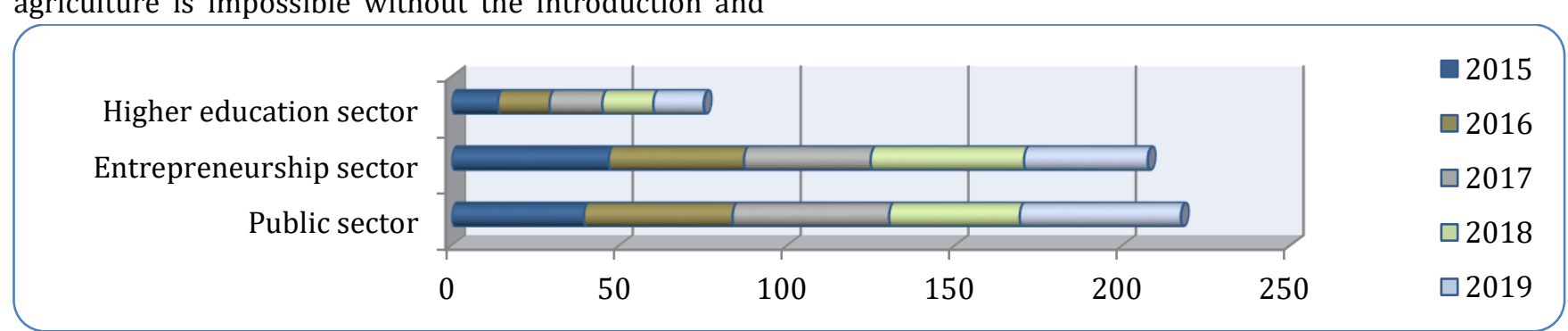

Figure 3. Scientific organizations by sectors of activity, implementing projects in innovative and investment development of agriculture of Ukraine, \%. 
In 2019, research and development for agriculture in Ukraine was performed by 950 organizations, including the public sector of the economy $48.1 \%$, business $36.9 \%$, the higher education sector $-15.0 \%$.

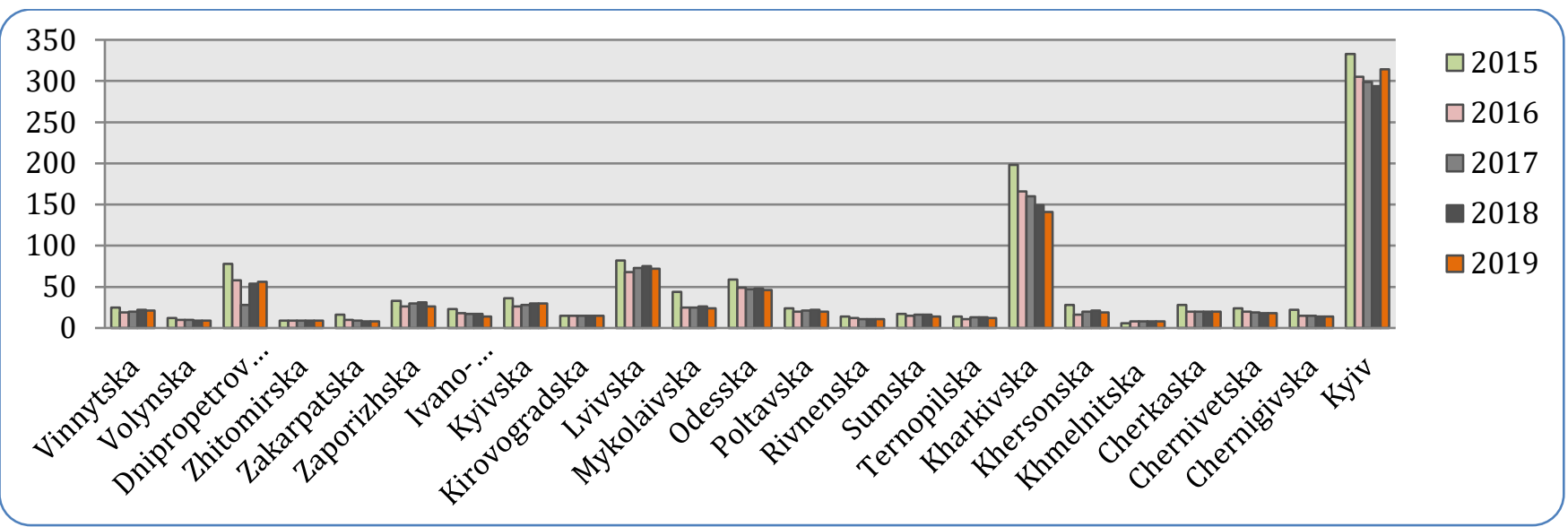

Figure 4. Organizations that carried out research and development of innovative and investment development of agriculture, by the regions of Ukraine, units.

Almost a third of the total number of scientific organizations is located in Kyiv, $15.5 \%$ - in Kharkiv, $7.8 \%$ - Lviv, $5.6 \%$ - Dnipropetrovskand 5.0\% - in Odessaregions (Figure 4). Almost a third of the total number of scientific organizations is located in
Kyiv $0.95 \%$ to the total number of employed population, in 2019 this figure decreased to $0.54 \%$. The total amount of public sector budget expenditures for R\&D in 2019 was equal to 496.26 million EUR, which is 256.4 million euros higher than in 2015 (Figure 5).

Expenditures on scientific and technical development, million EUR

Expenditures on applied scientific research, million EUR

Expenditures on basic research, million EUR

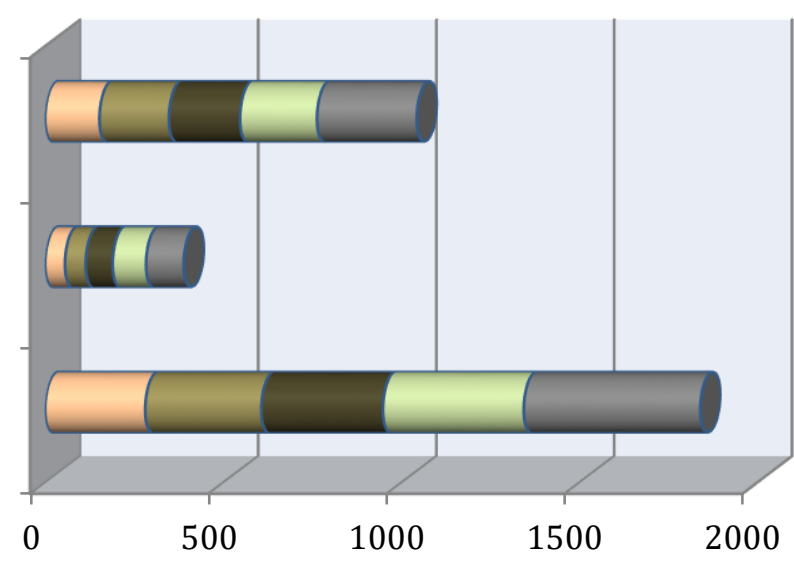

Figure 5. Expenditures of scientific organizations for implementation of projects in innovative and investment development of agriculture of Ukraine, million EUR

Innovative and investment activity of agricultural producers with the distribution of the average number of employees in agriculture is presented in Figures 6-7. Thus, in 2015-2016 the level of innovative and investment activity of agricultural producers was equal to $18 \%$, with the total number of enterprises $(27.73$ thousand units), of which $64.3 \%$ were investment active entities with technological (product or process) innovations. During the period 2017-2019, the share of investment-active agricultural producers implementing innovations increased by $5 \%$ or up to 29.13 units. Their level of innovation was $28.1 \%$ of the total number, of which $64.1 \%$ are active with technological (product or process) innovations. 


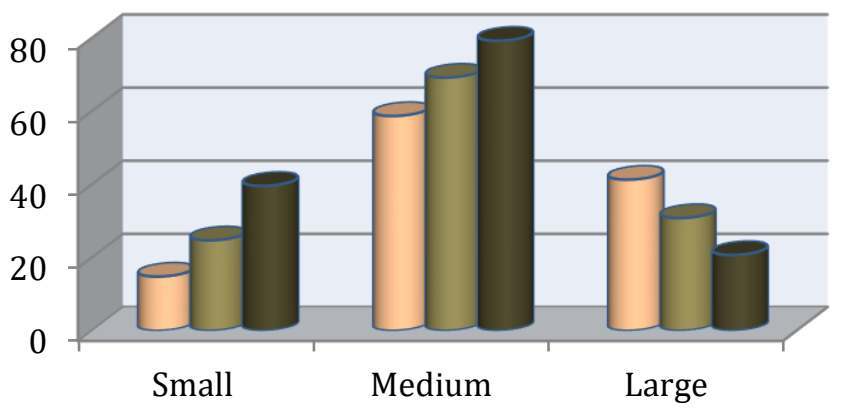

$\square$ Innovative and investment activity, \%

$\square$ Agricultural producers with technological (productive or process) innovations, \%

- Agricultural producers with non-technological (marketing or organizational) innovations, \%

Figure 6. Innovative and investment activity of Ukrainian producers with the distribution by the average number of employees in agriculture for 2015-2016, \%

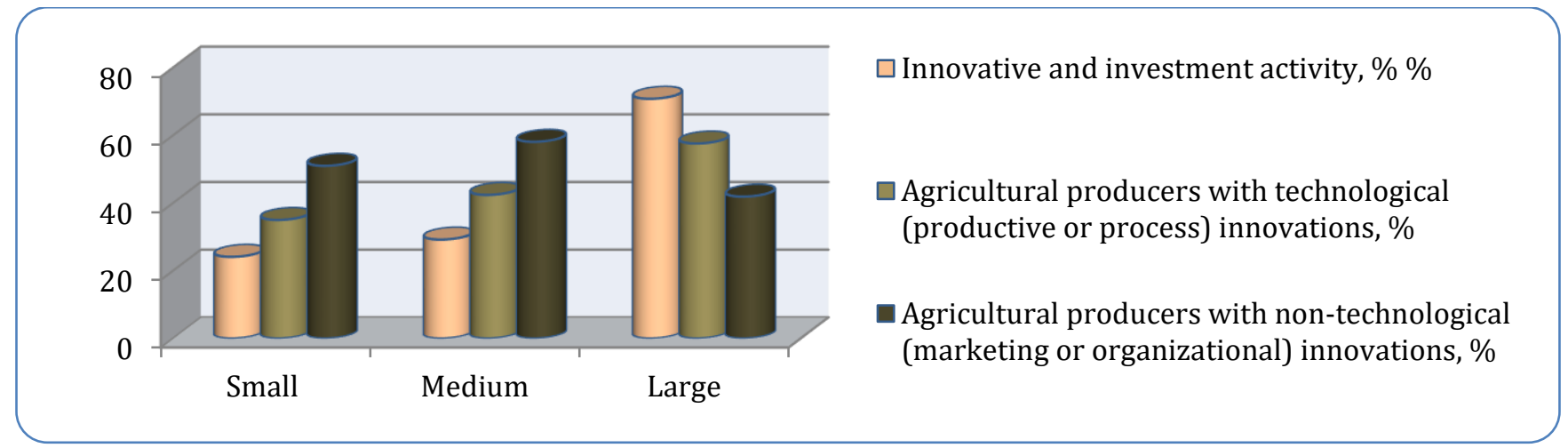

Figure 7. Innovative and investment activity of Ukrainian producers with the distribution by the average number of employees in agriculture for 2017-2019, \%.

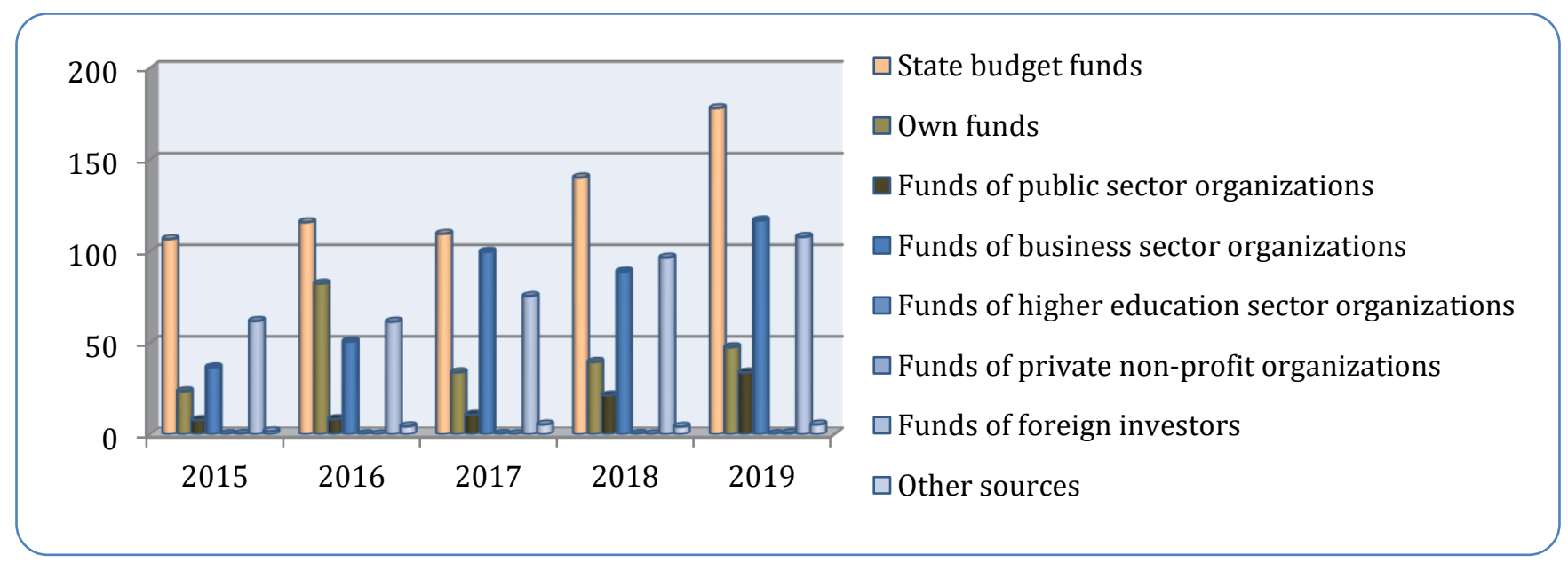

Figure 8. Sources of financing the costs of research and projects in the development of agriculture in Ukraine for 2015-2019, million EUR.

In Ukraine in 2019, the share of total expenditures in GDP for research and development in agriculture was $0.45 \%$, including at the expense of the state budget -
$0.16 \%$ (Figure 8 ). It should be noted that during the study period, the share of R\&D expenditures in the GDP of the EU-28 countries averaged $2.06 \%$ (Figure 9). 


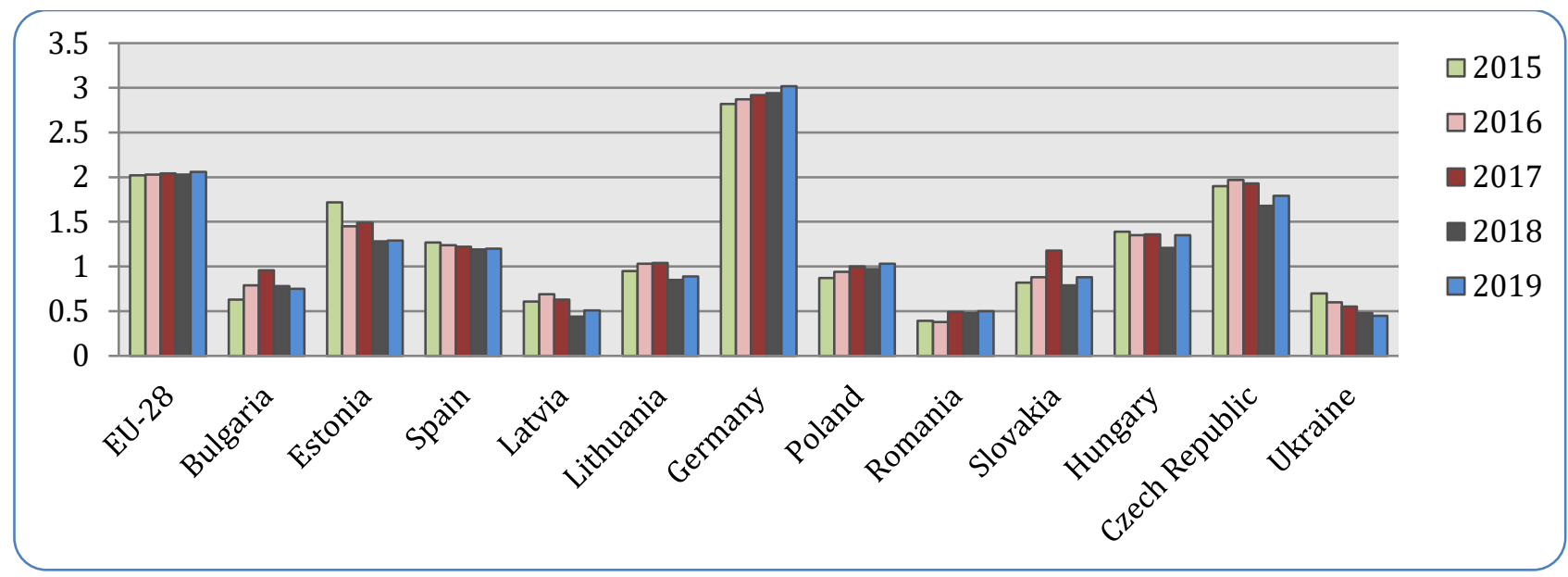

Figure 9. The share of expenditures on research and projects of agricultural development in GDP of EU-28 countries for the period 2015-2019, \%.

A larger share of the average level of funding for research and projects in agricultural development is in Germany - 3.02\%, Slovenia - 1.86\%, the Czech Republic - 1.79\%. The total costs for innovation in 2019 amounted to $100 \%$, of which $68.1 \%$ for the purchase of machinery, equipment and software and $0.4 \%$ for the acquisition of additional external knowledge. The development of agriculture in the world's leading countries is carried out according to the innovative and investment model, which is due to the growing need for high quality food resources and increasing the cost of their production.

According to UN forecasts, by 2050 the consumer needs of the population will increase on average to kcal per person per day, which is much more than the current level - on average $2700 \mathrm{kcal}$ per day. Given this trend, there will be an increase in global demand for basic foodstuffs. Thus, in 2020 the growth of world wheat production amounted to 806 million tons, in 2050 it is projected to increase to 950 million tons. Milk production by 2050 will reach 1222 million tons, beef will increase by more than $60 \%$, pork - by $77 \%$, poultry - by 2.1 times. Also noteworthy is the steady trend towards increasing the use of food resources for biofuel production as an alternative energy source, which is a consequence of rising oil and natural gas prices (Pavlova et al., 2018).

It should be noted that at present in the dairy industry of Ukraine the priority is the rational management of the industry and obtaining profitable quality raw materials for processing enterprises. In this case, for the productive use of animals, the chain "man-machineanimal" should work several times a day at regular intervals for 4-5 years (Vinichenko et al., 2020). Unfortunately, innovative transformations, which gradually cover the agricultural sector of the economy, affect only a limited number of agricultural producers in the animal husbandry sector, the intensification of innovative and investment activities are hindered by a number of destructive factors associated with limited production and technological innovations. Accordingly, the state must provide guarantees and support for the development of animal husbandry, ensure effective financing of innovative and investment projects and prioritize investment in this area. Thus, in 2019, the amount of capital investment utilized in animal husbandry per one conditional head of animal amounted to: cattle -6.3 thousand EUR, pigs - 3.15 thousand EUR, sheep and goats - 1.05 thousand EUR, bird - 0.21 thousand EUR (Figure 10).

The authors believe that to increase the investment attractiveness of animal husbandry in the institutions of state investment policy it is necessary to provide: increasing the amount of investment by expanding the possibilities of new sources of funding; comprehensive consideration of technical and technological, organizational and economic features of animal husbandry subsectors; giving priority in providing investments to those producers who are able to implement innovative-investment projects with high results according to reasonable parameters of the state of animal husbandry development. 


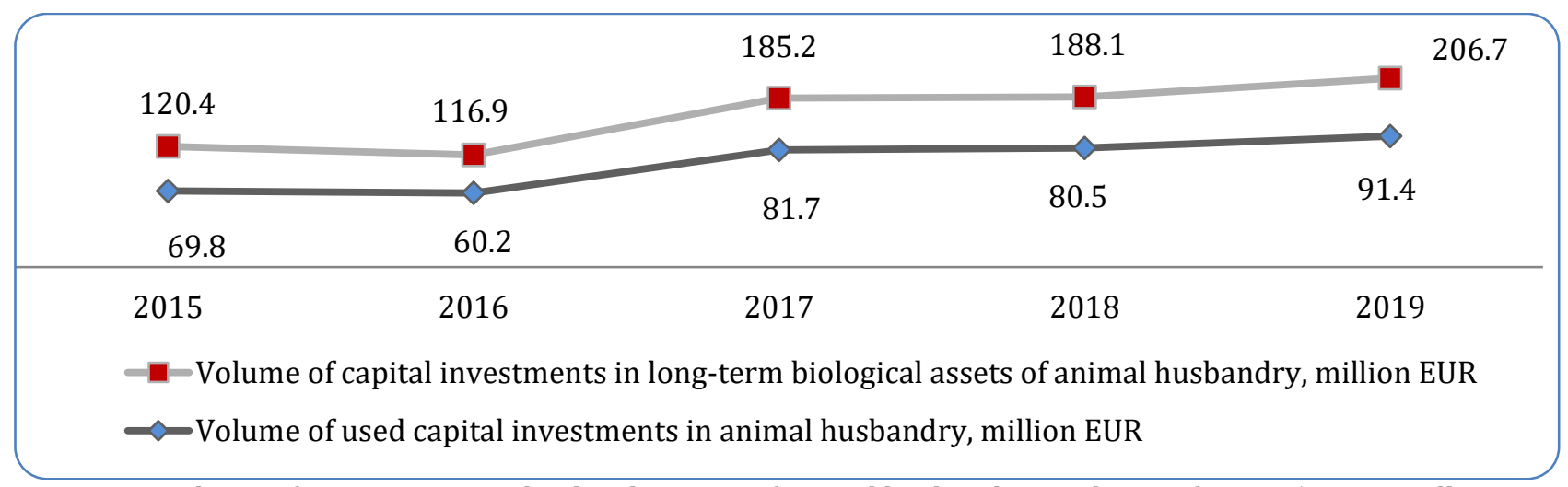

Figure 10. Volume of investments in the development of animal husbandry in Ukraine for 2015-2019, million EUR.

Analysis of the impact of foreign investment on agricultural output, gross value added and gross profit of agricultural producers allows concluding that they do not change the trend of their growth or slowdown. Thus, despite the decrease in foreign direct investment in the animal husbandry sector in $2015-2019$ by $27.8 \%$, there is a slight reduction in gross output - by $0.6 \%$. The rates of change in gross value added (increase in 2.0 times) and gross profit (decreaseby41.3\%) were largely determined by the specifics of production and technological processes and the price disparity for material resources (Figure 11).

\begin{tabular}{|c|c|c|c|c|}
\hline \multirow{3}{*}{$\begin{array}{l}7438.7 \\
-4767.6\end{array}$} & \multicolumn{3}{|c|}{8275.2} & 9020.4 \\
\hline & 1094.9 & & 9029.5 & 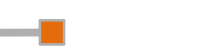 \\
\hline & 7084.8 & 7533.7 & 7371.5 & 7392.4 \\
\hline 1060.9 & 842.6 & 685.8 & 682.9 & 765.9 \\
\hline 2015 & $\begin{array}{l}406.6 \\
2016\end{array}$ & $2017^{209.3}$ & 2018 & $\begin{array}{l}\times 1 \\
2019\end{array}$ \\
\hline & $\begin{array}{l}- \text { Foreigr } \\
- \text { Gross o } \\
- \text { Gross v }\end{array}$ & $\begin{array}{l}\text { estment, milli } \\
\text { on EUR } \\
\text { l, million EUR }\end{array}$ & & \\
\hline
\end{tabular}

Figure 11. Volume of investments in the development of animal husbandry in Ukraine for 2015-2019, million EUR.

Innovative and investment projects with the involvement of foreign investors, for which the latter apply for additional tax, customs, credit benefits and insurance guarantees, should promote the creation of new jobs in enterprises in which investments are made; accompanied by the introduction of modern resourcesaving and environmentally friendly types of technologies; contribute to the reduction of energy consumption per unit of output; be focused on the most rational use of raw materials for agriculture. Thus, in agriculture of Ukraine in 2019, 441 innovative and investment projects with the cost of almost 1.22 billion EUR were implemented. Completion of these projects will create about 16 thousand new jobs (Figure 12). 


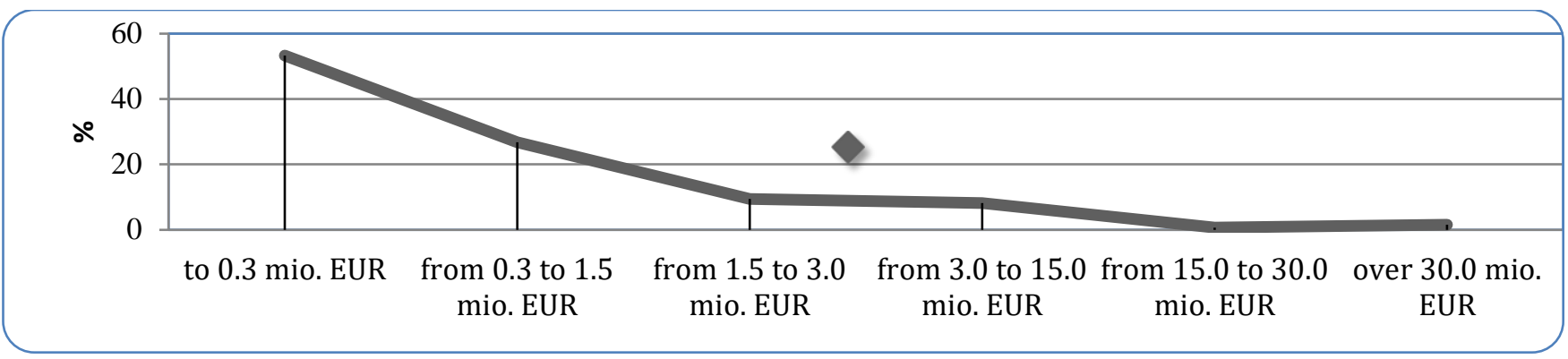

Figure 12. Implementation of innovative and investment projects in the development of the animal husbandry industry of Ukraine in terms of their value in 2019, million EUR.

The largest number of innovative and investment projects in the field of animal husbandry is implemented in the regions of the Steppe and Forest-Steppe zone of Ukraine, their cost varies from 3.0 thousand EUR to 0.3 billion EUR. Unfortunately, the most stable and the only source of funding for innovative and investment activities of agricultural producers in Ukraine engaged in animal husbandry are their own funds. However, their share in $2015-2019$ decreased by $2.35 \%$ in the total volume of all sources and amounted to $94.8 \%$; the share of funding from the state budget increased to $0.8 \%$ (increase by $0.4 \%$ ). The share of financing of innovative and investment projects at the expense of foreign investments has increased by $12.2 \%$ only for the last two years (2018-2019), the share of other sources of financing is $4.27 \%$.

Innovative and investment activity of agricultural producers in the animal husbandry sector is more exposed to risk than other areas of entrepreneurial activity, because there is almost no guarantee of a positive result in innovative entrepreneurship (Purvis and Downey., 2012). Innovation and investment development of agriculture in the animal husbandry sector are significantly affected by elements of uncertainty, which leads to a very high risk of innovative and investment activities. The authors should note that uncertainty arises under the influence of various objective reasons, the main of which are: economic and financial policy of the state, reforms in the tax system, exchange rate, inflation, and so on. The use of indicators of efficiency of innovative and investment projects in the animal-husbandry industry provides an opportunity to quantify the feasibility of decisions taken. Therefore, to take into account the qualitative characteristics of risk analysis, the authors have proposed a method of assessing the effectiveness of the mechanism of innovative and investment development of agriculture in general, which arise in the implementation of innovative and investment project. The methodology provides a comprehensive assessment of the factors that affect the effectiveness of innovative and investment development of agriculture in the field of animal husbandry; assessing the set of risks of implementing innovative development in the field of animal husbandry; situational approach to assessing the level of innovative and investment development of agricultural producers in the animal husbandry sector.

To assess the factors that affect the effectiveness of innovative and investment development of agricultural producers in the animal husbandry sector, it is advisable to use an adapted method of pairwise comparisons based on a multidimensional scale. The essence of the method of multidimensional comparative analysis is to process a multidimensional matrix and obtain a priority set of combinations of individual indicators for a given matrix characteristics (Purvis and Downey., 2012). This method of pairs can be used to assess the degree of influence of a set of external and internal factors on the effectiveness of innovative and investment development of agricultural producers in the animal husbandry industry and the construction of their priority series. The method of determining the priorities of factors involves the presence of three stages. At the first stage, a hierarchy is built as a structure of system requirements. Such a hierarchy allows to identify in a difficult situation the most important elements that determine the essence of the problem at the stage of evaluation, and to connect them with each other. In the second stage, pairwise comparisons are made in the matrix, which are formed at each level of the hierarchy. The result of this assessment should be a combination of external and internal priorities. Numerical values in matrices of pairwise 
comparisons can be obtained using an adapted scale of relative importance (Table 3).

Table 3. Scale of relative importance

\begin{tabular}{|c|c|c|}
\hline $\begin{array}{l}\text { Intensity of relative } \\
\text { importance }\end{array}$ & Significance of relative importance & Explanation \\
\hline 1 & Equally important & The same contribution of both elements \\
\hline 3 & A slight advantage & $\begin{array}{l}\text { Practice and reflection give preference to one } \\
\text { element over another }\end{array}$ \\
\hline 5 & A significant advantage & $\begin{array}{l}\text { Practice and reflection give a strong } \\
\text { advantage of one element over another }\end{array}$ \\
\hline 7 & A significant advantage & $\begin{array}{l}\text { One element is given such a great advantage } \\
\text { and it becomes almost significant }\end{array}$ \\
\hline 9 & A very strong advantage & $\begin{array}{l}\text { The obvious advantage of one element over } \\
\text { another is most strongly confirmed }\end{array}$ \\
\hline $2,4,6,8$ & $\begin{array}{l}\text { Intermediate values } \\
\text { adjacent considerations }\end{array}$ & Used in a compromise case \\
\hline $\begin{array}{l}\text { Inverse values of the } \\
\text { given numbers: } 1 / 2 \text {, } \\
1 / 3,1 / 4,1 / 5,1 / 6,1 / 7 \text {, } \\
1 / 8,1 / 9\end{array}$ & $\begin{array}{l}\text { If when comparing one element with } \\
\text { another one of the specified numbers } \\
\text { is received, then at return } \\
\text { comparison the return value is } \\
\text { received }\end{array}$ & $\begin{array}{l}\text { Used in cases of inverse excess, when the } \\
\text { compared element does not exceed, but is } \\
\text { inferior to another element }\end{array}$ \\
\hline
\end{tabular}

To assess the areas of the environment that affect the effectiveness of innovative and investment development of agricultural producers in the animal husbandry sector, the authors used a situational approach, which is based on the definition of significant situational variables (factors).

The authors should note that it is impossible to determine all the components that affect the system. For practical implementation, only those factors that have the greatest significance or influence can be considered. The concretization of the choice of factors may have different interpretations, but the whole set of factors is grouped by internal and external influential variables. In the course of the research the priority series of factors of influence of external and internal environment by means of a method of pair comparisons on the basis of a multidimensional scale were analyzed and constructed (Tables 4-5).
The given analysis shows that the sphere of external environment of direct action, which affects the efficiency of innovative-investment development of agricultural producers in the animal husbandry industry, is determined by the following factors: the spread of shadow mechanisms of state budget allocations for agricultural development (9.61\%), insolvency of agricultural producers to attract credit resources for innovative and investment development (9.57\%), the inability of agricultural producers to finance the implementation of innovative developments (9.38\%), the degradation of the resource potential of the agricultural sector $(8.81 \%)$, the inefficiency of the state regulation of innovative and investment processes in agriculture (8.06\%), unreasonableness of transformations of forms of ownership and management in agriculture (7.29\%), lack of substantiated state innovative-investment policy in agriculture (6.44\%).

Table 4. Calculation of priority factors of the external environment influencing the effectiveness of innovativeinvestment development of the animal husbandry industry of Ukraine

\begin{tabular}{|c|c|c|c|c|}
\hline The factors & W & $\begin{array}{l}\text { Value } \\
\sqrt[16]{W}\end{array}$ & $\begin{array}{c}\text { Degreeofinfluenc } \\
\text { eofthefactor }\end{array}$ & Rank \\
\hline $\begin{array}{l}\text { 1. Inefficiency of the system of state regulation of innovative and } \\
\text { investment processes in agriculture }\end{array}$ & 151.875 & 1.3688 & 0.0806 & 5 \\
\hline 2. Degradation of domestic scientific potential & 0.08019 & 0.8541 & 0.0503 & 11 \\
\hline $\begin{array}{l}\text { 3. Lack of effective state control over the implementation of } \\
\text { economic legislation }\end{array}$ & 1.4175 & 1.0220 & 0.0602 & 9 \\
\hline
\end{tabular}


4. Unfoundedness of transformations of forms of ownership and management in the field of animal husbandry

\begin{tabular}{|c|c|c|c|}
\hline 30.294 & 1.2376 & 0.0729 & 6 \\
\hline 4.139942 & 1.0929 & 0.0644 & 7 \\
\hline 3.13632 & 1.0741 & 0.0633 & 8 \\
\hline 0.002001 & 0.6782 & 0.0399 & 12 \\
\hline 0.000122 & 0.5695 & 0.0335 & 15 \\
\hline 627.264 & 1.4957 & 0.0881 & 4 \\
\hline 0.000606 & 0.6294 & 0.0371 & 14 \\
\hline $5.56 \mathrm{E}-05$ & 0.5421 & 0.0319 & 16 \\
\hline 2509.056 & 1.6311 & 0.0961 & 1 \\
\hline 0.000194 & 0.5861 & 0.0345 & 13 \\
\hline 1710.72 & 1.5925 & 0.0938 & 3 \\
\hline 0.7425 & 0.9816 & 0.0578 & 10 \\
\hline 2376 & 1.6255 & 0.0957 & 2 \\
\hline
\end{tabular}

Table 5. Calculation of the priority factors of the internal environment of influence on efficiency of innovative and investment development of animal husbandry of Ukraine.

5. Lack of grounded state innovative and investment policy in agriculture

6. Growth of the shadow economy in agriculture

7. Imperfection of the existing infrastructure of the market of science-intensive products of the animal husbandry industry

8. Imperfection of the mechanism of commercialization of scientific development in the field of animal husbandry

9. Degradation of resource potential of agriculture

10. Lack of integration links between agricultural science and agricultural producers

11. Lack of state concept of support and innovative and investment development of the animal husbandry industry

12. Dissemination of shadow mechanisms for the use of budget funds allocated by the state for agricultural development

13. Lack of effective mechanisms for the development of the market for science-intensive products in the animal husbandry industry

14. Failure of agricultural producers to finance the implementation of innovative developments

15. Low investment attractiveness of the animal husbandry industry in agriculture

16. Failure of agricultural producers to attract credit resources for innovative development

$\sum=16.98$

\begin{tabular}{|c|c|c|c|c|}
\hline The factors & W & $\sqrt[16]{W}$ & $\begin{array}{l}\text { Degreeofinfluenc } \\
\text { eofthefactor }\end{array}$ & Rank \\
\hline $\begin{array}{l}\text { 1. Negative results of the functioning of agricultural producers in } \\
\text { previous years }\end{array}$ & 2258.1 & 1.6204 & 0.0961 & 1 \\
\hline $\begin{array}{l}\text { 2. Lack of financial resources of agricultural producers for the } \\
\text { acquisition and implementation of innovative developments }\end{array}$ & 0.3234 & 0.9319 & 0.0553 & 11 \\
\hline $\begin{array}{l}\text { 3. Disadvantages of state regulation of innovative and investment } \\
\text { policy in agriculture }\end{array}$ & 0.3920 & 0.9432 & 0.0559 & 10 \\
\hline 4. Inefficient use of resource potential by agricultural producers & 66.825 & 1.3003 & 0.0771 & 4 \\
\hline $\begin{array}{l}\text { 5. Insufficiency and inability of agricultural producers of animal } \\
\text { husbandry to be participants in the market of credit resources }\end{array}$ & 1.2251 & 1.0128 & 0.0600 & 9 \\
\hline $\begin{array}{l}\text { 6. Low technological process of agricultural production of animal } \\
\text { husbandry }\end{array}$ & 1012.5 & 1.5411 & 0.0914 & 2 \\
\hline $\begin{array}{l}\text { 7. Difficulties of farms in the industry to establish effective } \\
\text { relationships with potential investors and research organizations }\end{array}$ & 194.05 & 1.3899 & 0.0824 & 3 \\
\hline $\begin{array}{l}\text { 8. Lack of state support for innovative and investment } \\
\text { development of the animal husbandry industry }\end{array}$ & 0.0469 & 0.8260 & 0.0490 & 13 \\
\hline $\begin{array}{l}\text { 9. Insufficient motivation of agricultural producers in the animal } \\
\text { husbandry sector to implement innovative developments }\end{array}$ & 8.8209 & 1.1458 & 0.0679 & 5 \\
\hline 10. Weak pace of modernization of material and technical base & 0.0445 & 0.8233 & 0.0488 & 14 \\
\hline
\end{tabular}


and use of the latest advances in genetics and technological development in the field of animal husbandry

11. Lack of skilled labor in agriculture, the outflow of specialists

12. Lack of an effective system of resource conservation in agricultural producers

13. Insufficient interest of agricultural producers in the need for innovative and investment development of production and technological processes in the field of animal husbandry

14. Lack of effective internal economic mechanisms to increase the efficiency of animal husbandry production

15. Insufficiently effective system of risk management and monitoring in agricultural entrepreneurship

15. Weak effectiveness of investment mechanisms of innovativeinvestment development of agricultural producers

\begin{tabular}{cccc}
5.0984 & 1.1072 & 0.0656 & 7 \\
3.315 & 0.5254 & 0.0312 & 16 \\
0.12128 & 0.8765 & 0.0520 & 12 \\
4.95 & 1.1051 & 0.0655 & 8 \\
8.46806 & 1.1428 & 0.0678 & 6 \\
0.00013 & 0.5740 & 0.0340 & 15 \\
& & $\sum=16.87$ & \\
\hline
\end{tabular}

The calculation of a number of priority factors of the internal environment that affect the effectiveness of innovative and investment development of agricultural producers in the animal husbandry sector showed that: negative results of agricultural producers of animal husbandry in the past years are $9.61 \%$, low technological process of agricultural production $9.14 \%$, the difficulties of farms in establishing effective relations with potential investors and scientific organizations - 8.24\%, inefficient use of resource potential of agricultural producers $-7.71 \%$, insufficient motivation of agricultural producers for the implementation of innovative developments - 6.79\%, insufficiently effective risk management and monitoring system for agricultural producers $-6.78 \%$, lack of skilled labor in agriculture, outflow of specialists $-6.56 \%$.

According to authors' double approach to assessing the factors influencing the effectiveness of innovative and investment development of agricultural producers - in terms of state support and from the standpoint of situational innovation management of economic entities, as well as the strength and number of objects subject to their influence, it is possible to allocate fundamental and specific risks operating in the field of innovative and investment activity. Given the current state of production in the animal husbandry industry in Ukraine, in proposed methodology the authors consider it appropriate to emphasize the fundamental risks.

At the first stage of risk management, it is necessary to develop a general strategy of innovative and investment development of the animal husbandry industry in the region. Then general strategic directions are developed, the probability of risky situations in the market is forecasted. At the next stage, the overall level of aggregate risk is assessed. Based on this assessment, the development of specific functional management mechanisms for each component of aggregate risk is carried out. At the final stages of the algorithm the organization of control and functional analysis of the effectiveness of risk management is provided. The assessment of the level of aggregate risk of innovative and investment development of the animal husbandry industry is based on partial functional criteria of component risks (economic, organizational, political and social). The calculation of the forecast of the value of the total fundamental risk of the implementation of innovative and investment projects of agricultural producers in the animal husbandry industry assumes that its level will increase almost twice (from 3.87 in 2018 to 7.60 in 2020 p.), (Table 6). In this system of risks the greatest growth of threats of group of economic risks is forecasted. The calculation mechanism for determining the aggregate criterion is presented in Table 7. The total criterion for the effectiveness of innovative and investment development of the animal husbandry industry is calculated by formula (2) (Prokopenko et al., 2019b):

$C I I D=\sum_{i=1}^{n} K_{i} d_{i}$,

where: $K_{i}$ - the value of partial functional criteria for the effectiveness of structural components; $d_{i}$ - the share of significance of the functional components of the efficiency of innovative and investment development of the animal husbandry industry. According to the results of the study, the level of efficiency of innovative and investment development of the animal husbandry industry is projected to increase $57.9 \%$ (from 5.44in 
2018 to 8.60 in 2020) under the influence of positive processes in industry production and improvement state policy of innovative and investment transformations in agriculture.

Table 6. Forecast of fundamental risks of innovative andinvestment development of the animal husbandry industry in Ukraine.

\begin{tabular}{|c|c|c|c|c|c|c|c|}
\hline \multirow{2}{*}{ Indicator } & \multirow{3}{*}{$\begin{array}{c}\text { Partial } \\
\text { coefficient }\end{array}$} & \multicolumn{4}{|c|}{ Score } & \multirow{2}{*}{\multicolumn{2}{|c|}{$\begin{array}{l}\text { Forecast } \\
\text { for } 2020\end{array}$}} \\
\hline & & \multicolumn{2}{|c|}{2018} & \multicolumn{2}{|c|}{2019} & & \\
\hline & & points & $\sum$ & points & $\Sigma$ & points & $\Sigma$ \\
\hline
\end{tabular}

Economic

1. Lack of state policy of innovative andinvestment development of the animal husbandry industry

$\begin{array}{lllllll}0.08 & 5 & 0.4 & 7 & 0.56 & 9 & 0.72\end{array}$

2. Degradation of production and resource potential of the animal husbandry industry

3. Unavailability of credit resources for agricultural producers

4. Lack of a grounded economic concept for the development of agricultural producers in the field of animal husbandry

5. Low investment attractiveness of agricultural producers

$\begin{array}{lllllll}0.07 & 4 & 0.28 & 8 & 0,56 & 8 & 0.56\end{array}$

$\begin{array}{lllllll}0.07 & 3 & 0.21 & 7 & 0.49 & 9 & 0.63\end{array}$

$\begin{array}{lllllll}0.05 & 4 & 0.20 & 7 & 0.35 & 9 & 0.45\end{array}$

$\begin{array}{lllllll}0.05 & 4 & 0.20 & 6 & 0.30 & 9 & 0.45\end{array}$

Organizational

1. Imperfection of the existing market infrastructure in the market of science-intensive products

$\begin{array}{lllllll}0.05 & 3 & 0.15 & 5 & 0.25 & 8 & 0.40\end{array}$

2. Lack of an effective integration mechanism between industry science and agricultural producers

$\begin{array}{lllllll}0.04 & 4 & 0.16 & 7 & 0.28 & 9 & 0.36\end{array}$

3. The destructive nature of tax policy

$\begin{array}{lllllll}0.06 & 3 & 0.18 & 8 & 0.48 & 9 & 0.54\end{array}$

4. Inconsistency of existing forms of management with real economic conditions

$\begin{array}{lllllll}0.04 & 3 & 0.12 & 5 & 0.20 & 8 & 0.32\end{array}$

5. Non-compliance of science-intensive products with the requirements for their quality, impossibility of use by the consumer, aging of technology or equipment

$\begin{array}{lllllll}0.03 & 4 & 0.12 & 6 & 0.18 & 8 & 0.24\end{array}$

\begin{tabular}{|c|c|c|c|c|c|c|c|}
\hline \multicolumn{8}{|l|}{ Political } \\
\hline $\begin{array}{l}\text { 1. Lack of harmonization of current legislation with the } \\
\text { legislation of European countries in the field of investment }\end{array}$ & 0.05 & 5 & 0.25 & 7 & 0.35 & 9 & 0.45 \\
\hline $\begin{array}{l}\text { 2. Inefficiency of state policy to increase the investment } \\
\text { attractiveness of the animal husbandry industry }\end{array}$ & 0.06 & 3 & 0.18 & 5 & 0.30 & 10 & 0.6 \\
\hline 3. Lack of state support for the animal husbandry industry & 0.04 & 3 & 0.12 & 6 & 0.24 & 8 & 0.32 \\
\hline $\begin{array}{l}\text { 4. Lack of the concept of food and economic security of the } \\
\text { animal husbandry industry }\end{array}$ & 0.04 & 4 & 0.16 & 6 & 0.24 & 8 & 0.32 \\
\hline $\begin{array}{l}\text { 5. Lack of effective mechanisms for commercialization and } \\
\text { promotion of science-intensive products in the market }\end{array}$ & 0.03 & 4 & 0.12 & 6 & 0.18 & 8 & 0.24 \\
\hline \multicolumn{8}{|l|}{$\begin{array}{ll} & \\
\end{array}$} \\
\hline 1. Degradation of scientific potential in agriculture & 0.06 & 3 & 0.18 & 5 & 0.30 & 8 & 0.48 \\
\hline $\begin{array}{l}\text { 2. Significant transformation of consumer preferences in the } \\
\text { market of science-intensive products }\end{array}$ & 0.05 & 4 & 0.20 & 6 & 0.30 & 9 & 0.45 \\
\hline $\begin{array}{l}\text { 3. Lack of state support for the development of integration of } \\
\text { branch science with production }\end{array}$ & 0.05 & 4 & 0.20 & 7 & 0.35 & 9 & 0.45 \\
\hline $\begin{array}{l}\text { 4. Degradation of human resources in the animal husbandry } \\
\text { industry }\end{array}$ & 0.04 & 5 & 0.20 & 7 & 0.28 & 6 & 0.24 \\
\hline $\begin{array}{l}\text { 5. Lack of motivation of agricultural producers to implement } \\
\text { innovative developments }\end{array}$ & 0.04 & 4 & 0.16 & 6 & 0.24 & 7 & 0.28 \\
\hline & & \multicolumn{2}{|c|}{3.87} & & & \multicolumn{2}{|c|}{7.60} \\
\hline
\end{tabular}


The lack of clearly defined evaluation parameters allows adapting this flexible tool for comprehensive assessment of the functioning of the innovative and investment mechanism of the agricultural market to changing economic conditions of agricultural producers in the intersectoral interaction of agricultural development.

Table 7. Forecast of the level of efficiency of innovative and investment development of agricultural producers in the animal husbandry sector of Ukraine

\begin{tabular}{|c|c|c|c|c|c|c|c|c|c|}
\hline \multirow[b]{2}{*}{ Criterion } & \multicolumn{2}{|c|}{2018} & \multicolumn{4}{|c|}{2019} & \multicolumn{3}{|c|}{2020} \\
\hline & 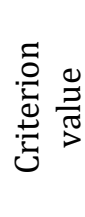 & 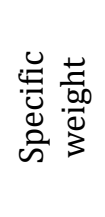 & $\begin{array}{c}\text { Aggregate } \\
\text { criterion of } \\
\text { innovation and } \\
\text { investment } \\
\text { development }\end{array}$ & 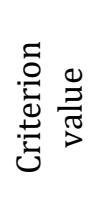 & 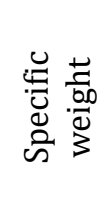 & $\begin{array}{c}\text { Aggregate } \\
\text { criterion of } \\
\text { innovation and } \\
\text { investment } \\
\text { development }\end{array}$ & 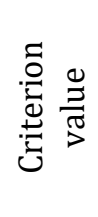 & 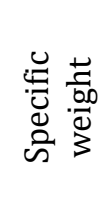 & $\begin{array}{c}\text { Aggregate } \\
\text { criterion of } \\
\text { innovation and } \\
\text { investment } \\
\text { development }\end{array}$ \\
\hline $\begin{array}{l}\text { Increasing the volume of } \\
\text { agricultural production } \\
\text { and processing products } \\
\text { of the animal husbandry } \\
\text { industry }\end{array}$ & 4 & 0.18 & 0.72 & 5 & 0.15 & 0.75 & 7 & 0.17 & 1.19 \\
\hline $\begin{array}{l}\text { Strengthening the } \\
\text { resource potential of } \\
\text { agricultural producers } \\
\text { in the animal husbandry } \\
\text { industry }\end{array}$ & 6 & 0.11 & 0.66 & 7 & 0.13 & 0.91 & 9 & 0.14 & 1.26 \\
\hline $\begin{array}{l}\text { The growth of } \\
\text { investment } \\
\text { attractiveness } \\
\text { agricultural producers } \\
\text { in the animal husbandry } \\
\text { industry }\end{array}$ & 5 & 0.15 & 0.75 & 6 & 0.11 & 0.66 & 8 & 0.12 & 0.96 \\
\hline $\begin{array}{l}\text { High quality animal } \\
\text { husbandry products }\end{array}$ & 6 & 0.12 & 0.72 & 7 & 0.10 & 0.7 & 8 & 0.12 & 0.96 \\
\hline $\begin{array}{l}\text { Inflow of investment } \\
\text { resources in the field of } \\
\text { animal husbandry }\end{array}$ & 6 & 0.10 & 0.6 & 7 & 0.11 & 0.77 & 8 & 0.12 & 0.96 \\
\hline $\begin{array}{l}\text { Growth of economic } \\
\text { efficiency of functioning } \\
\text { of } \\
\text { producers of angicultural } \\
\text { husbandry }\end{array}$ & 4 & 0.09 & 0.36 & 6 & 0.12 & 0.72 & 7 & 0.13 & 0.91 \\
\hline $\begin{array}{l}\text { Development } \text { of an } \\
\text { integration mechanism } \\
\text { between scientific } \\
\text { organizations r and } \\
\text { agricultural producers } \\
\text { of animal husbandry }\end{array}$ & 6 & 0.05 & 0.30 & 7 & 0.09 & 0.63 & 8 & 0.05 & 0.40 \\
\hline $\begin{array}{l}\text { Strengthening scientific } \\
\text { potential in agriculture }\end{array}$ & 6 & 0.12 & 0.72 & 6 & 0.13 & 0.78 & 7 & 0.09 & 0.63 \\
\hline $\begin{array}{l}\text { Ensuring food and } \\
\text { economic security of the } \\
\text { state and the region }\end{array}$ & 3 & 0.06 & 0.18 & 5 & 0.05 & 0.25 & 7 & 0.06 & 0.42 \\
\hline $\begin{array}{l}\text { Availability of effective } \\
\text { ways to promote animal } \\
\text { husbandry products in } \\
\text { the foreign market }\end{array}$ & 3 & 0.08 & 0.24 & 6 & 0.09 & 0.54 & 7 & 0.08 & 0.56 \\
\hline
\end{tabular}




\begin{tabular}{|c|c|c|c|c|c|c|c|c|c|}
\hline $\begin{array}{l}\text { Growing rates of } \\
\text { production volumes and } \\
\text { quality of animal } \\
\text { husbandry products }\end{array}$ & 5 & 0.04 & 0.20 & 6 & 0.05 & 0.30 & 7 & 0.05 & 0.35 \\
\hline & & 1 & 5.44 & & 1 & 7.01 & & 1 & 8.60 \\
\hline
\end{tabular}

Note: values can vary from 1 to 10: 1 - degradation of structural and functional components of innovative and investment development; 10 - effective development.

\section{CONCLUSIONS}

The actualization of the innovative and investment model of agricultural development for Ukraine is due to the diffusion (spread) of innovations related to the production of animal husbandry products. Innovative changes cannot be considered cardinal, as they reflect the traditional reproductive process of development of a particular agricultural sector (including animal husbandry), which seeks to increase food production by improving the quality of the material component of the production process. Thus, the priority areas of innovative and investment development of agriculture in Ukraine in both vertically integrated and coordinated sectors of the organizational and technological chain in which agricultural producers operate, should be aimed at modifying economic relations under existing forms, methods and mechanisms of state support. At the same time, the system of state support must be flexible, meet both current and long-term needs of agriculture. When forming the structure of expenditures for research and development in the state budget, it is necessary to focus primarily on investment support for structural changes in the intersectoral space, the introduction of innovations in production and technological processes, as well as the formation of Ukrainian food market infrastructure; creation of conditions for optimization of the financial and credit mechanism of servicing agricultural producers, introduction of credit cooperation in rural areas and formation of an insurance system for agricultural activities. In addition, the state must take into account the factors influencing the perception of agricultural producers of external and internal innovations, which operate in the conditions of an aggressive strategy, European integration and innovative technologies.

\section{REFERENCES}

Castellacci, F. and J. M. Natera. 2013. The dynamics of national innovation systems: A panel cointegration analysis of the coevolution between innovative capability and absorptive capacity. Research Policy, 42: 579-594.

Cherep, A. V. and N. Chernikova. 2019. Innovative Approaches to Determination of Economic Digitization in the Modern Stage of Enterprise Development. Research Policy, 42: 579-594.

Freeman, C. 1987. Technology policy and economic performance: Lessons from Japan. Frances Printer Publishers, London.

Hekkert, M. P., R. A. A. Suurs, S. O. Negro, S. Kuhlmann and R. E. H. M. Smits. 2007. Functions of innovation systems: A new approach for analysing technological change. Technological Forecasting and Social Change, 74: 413-432.

Humenyuk, H., V. Stefanyk, V. Yemtsev, K. Salyga, T. Pavliuk and H. Pavlova. 2020. Dichotomy and Interdependence in Strategic Management Concerning Innovative and Investing Activities of Organizations. Academy of Strategic Management Journal, 19: 1-8.

Kasianenko, V. 2011. Foreign experience in managing the innovative potential of the economy and the possibility of its use in Ukraine. Marketing and Innovation Management, 4: 200-204.

Khalatur, S. 2017. Finding of alternative sources of innovations funding in agriculture. Technology audit and production reserves, 3: 20-25.

Khalatur, S., S. Khaminich, O. Budko, O. Dubovych and 0. Karamushka. 2020. Multiple system of innovationinvestment decisions adoption with synergetic approach usage. Entrepreneurship and Sustainability Issues, 7: 2745-2763.

Kleinknecht, A. 1987. Testing Long Waves. Innovation Patterns in Crisis and Prosperity. Palgrave Macmillan UK, p. 17-50.

Lundvall, B. Å. 2007. National Innovation SystemsAnalytical Concept and Development Tool. Industry \& Innovation, 14: 95-119.

Mensh, G. 1975. Das technologische Patt: Innovationen ubervinden die Depression. Frankfurt am Main. 
Nelson, R., D. Mowery, J. Fagerberg and K. Pavitt. 2006. Innovation Processes. Oxford University Press, Oxford.

Patel, P. and K. Pavitt. 1994. The nature and economic importance of national innovation systems. STI Review, 14: 9-32.

Pavlova, H. Y., O. V. Honcharenko and Y. L. Yakubenko. 2018. Institutionalization of innovation transformations of agricultural production in the context of providing economic security. Scientific Bulletin of Polissia, 1: 83-87.

Pavlova, S. A., A. V. Kyzmina, E. S. Pestereva and G. E. Zakharova. 2019. The effect of alfalfa sowing on the productivity of legume-grass herbage in the conditions of Central Yakutia. Agrarian Science, 325: 37-40.

Perroux, F. 1950. Economic Space: Theory and Applications. The Quarterly Journal of Economics, 64: 89.

Prokopenko, O., V. Omelyanenko and J. Klisinski. 2019a. Innovation Policy Developmet Conceptual Framework for National Resource Security Providing. Journal of Environmental Management and Tourism, 9: 1099.

Prokopenko, O., M. Slatvinskyi, N. Biloshkurska, M. Biloshkurskyi and V. Omelyanenko. 2019b.
Methodology of national investment and innovation security analytics. Problems and Perspectives in Management, 17: 380-394.

Prokopenko, O. V., V. A. Omelianenko and Y. I. Eremenko. 2014. Role of international factor in innovation ecosystem formation. Economic Annals-XXI, 3: 4-7.

Purvis, G. and L. Downey. 2012. A model for sustainablycompetitive agriculture. Agroecology and Strategies for Climate Change. Sustainable Agriculture Reviews, 8: 35-65.

Trusova, N., N. Tanklevska and O. Prystemskyi. 2019. Venture Financing of the Subjects of Agrarian Business. Accounting and Finance: 99-108.

Vinichenko, I. I., N. V. Trusova, L. M. Kurbatska, M. A. Polehenka and V. O. Oleksiuk. 2020. Imperatives of Quality Insuring of the Production Cycle and Effective Functioning Process of the Enterprises of Agro-Product Subcomplex of Ukraine. Journal of Advanced Research in Law and Economics, 11: 1462.

Winter, S. G. 1984. Schumpeterian competition in alternative technological regimes. Journal of Economic Behavior \& Organization, 5: 287-320.

Publisher's note: EScience Press remains neutral with regard to jurisdictional claims in published maps and institutional affiliations.

Open Access This article is licensed under a Creative Commons Attribution 4.0 International License, which permits use, sharing, adaptation, distribution and reproduction in any medium or format, as long as you give appropriate credit to the original author(s) and the source, provide a link to the Creative Commons license and indicate if changes were made. The images or other third-party material in this article are included in the article's Creative Commons license, unless indicated otherwise in a credit line to the material. If material is not included in the article's Creative Commons license and your intended use is not permitted by statutory regulation or exceeds the permitted use, you will need to obtain permission directly from the copyright holder. To view a copy of this license, visit http://creativecommons.org/licenses/by/4.0/. 